\title{
Impact of Backbone Amide Substitution at the Meta- and Para-Positions on the Gas Barrier Properties of Polyimide
}

\author{
Qian Wen ${ }^{1}\left(\mathbb{D}\right.$, Ao Tang ${ }^{2}$, Chengliang Chen ${ }^{2}$, Yiwu Liu ${ }^{2, *} \mathbb{C}$, Chunguang Xiao ${ }^{1}$, Jinghua Tan ${ }^{2} \mathbb{D}$ and Duxin $\mathrm{Li}^{1, *}$ \\ 1 State Key Laboratory of Powder Metallurgy, Central South University, Changsha 410083, China; \\ wenqian0088@126.com (Q.W.); chunguang4715@126.com (C.X.) \\ 2 Key Laboratory of Advanced Packaging Materials and Technology of Hunan Province, National and Local \\ Joint Engineering Center of Advanced Packaging Materials R \& D Technology, School of Packaging and \\ Materials Engineering, Hunan University of Technology, Zhuzhou 412007, China; tangao1234@163.com (A.T.); \\ chenchengliangc@163.com (C.C.); tjh@hut.edu.cn (J.T.) \\ * Correspondence: liuyiwu@hut.edu.cn (Y.L.); liduxin6404@csu.edu.cn (D.L.)
}

Citation: Wen, Q.; Tang, A.; Chen, C. Liu, Y.; Xiao, C.; Tan, J.; Li, D. Impact of Backbone Amide Substitution at the Meta- and Para-Positions on the Gas Barrier Properties of Polyimide. Materials 2021, 14, 2097. https:// doi.org/10.3390/ma14092097

Academic Editor: Volker Abetz

Received: 18 March 2021

Accepted: 7 April 2021

Published: 21 April 2021

Publisher's Note: MDPI stays neutral with regard to jurisdictional claims in published maps and institutional affiliations.

Copyright: (c) 2021 by the authors. Licensee MDPI, Basel, Switzerland. This article is an open access article distributed under the terms and conditions of the Creative Commons Attribution (CC BY) license (https:// creativecommons.org/licenses/by/ $4.0 /)$

\begin{abstract}
This study designed and synthesised a meta-amide-substituted dianiline monomer (mDABA) as a stereoisomer of DABA, a previously investigated para-amide-substituted dianiline monomer. This new monomer was polymerised with pyromellitic dianhydride (PMDA) to prepare a polyimide film (m-DABPI) in a process similar to that employed in a previous study. The relationship between the substitution positions on the monomer and the gas barrier properties of the polyimide film was investigated via molecular simulation, wide-angle $X$-ray diffraction (WXRD), and positron annihilation lifetime spectroscopy (PALS) to gain deeper insights into the gas barrier mechanism. The results showed that compared with the para-substituted DABPI, the m-DABPI exhibited better gas barrier properties, with a water vapour transmission rate (WVTR) and an oxygen transmission rate (OTR) as low as $2.8 \mathrm{~g} \cdot \mathrm{m}^{-2} \cdot \mathrm{d}^{-1}$ and $3.3 \mathrm{~cm}^{3} \cdot \mathrm{m}^{-2} \cdot \mathrm{d}^{-1}$, respectively. This was because the metalinked polyimide molecular chains were more tightly packed, leading to a smaller free volume and lower molecular chain mobility. These properties are not conducive to the permeation of small molecules into the film; thus, the gas barrier properties were improved. The findings have significant implications for the structural design of high-barrier materials and could promote the development of flexible display technology.
\end{abstract}

Keywords: polymerisation; flexible display technology; dianiline monomer

\section{Introduction}

Polyimide (PI) is a class of polymeric material with excellent comprehensive performance [1,2]. PI demonstrates outstanding thermal and mechanical properties, good dimensional stability, and excellent electrical insulation due to its unique imide ring structure [3]. Moreover, the dianiline/dianhydride monomer of polyimide can be designed and synthesised flexibly and easily [4]. Further, their raw materials are diverse and inexpensive, leading to PI's excellent structural designability. PI is widely used in many fields, including aerospace, machinery, electronics, and microelectronics $[5,6]$.

The advancement of new technologies within microelectronics has posed increasingly high requirements for the properties of polymeric materials. For example, the polymeric substrate materials used in the packaging of flexible organic light-emitting devices (OLED) must withstand temperatures up to $400{ }^{\circ} \mathrm{C}$ and have a permeability several orders of magnitude lower than that of traditional high-barrier materials [7-9]. While such strict performance requirements cannot be achieved by traditional high-barrier polymeric materials, the excellent heat resistance of PI makes it a promising substrate candidate $[10,11]$. However, the application of traditional PI as an OLED substrate is limited by its low barrier properties [12,13]. Fortunately, it is possible to synthesise PI with high barrier properties thanks to its excellent structural designability $[14,15]$ 
Relevant studies have shown that chemical structural design is among the most effective ways to improve the intrinsic barrier properties of PI. Existing studies have focused on introducing rigid planar (carbazole, fluorene rings, etc.) or amide structures that can realise interchain forces to prepare high barrier PI with excellent performance [16-18]. In our previous work, the high barrier PI was generated by the reaction of a commercial p-diamine monomer (DADA) containing an amide group with commercial pyrophthalic anhydride (PMDA). However, much remains unknown about the impact of subtle changes in monomer structure on the gas permeation properties of such polymers $[19,20]$. This study synthesised a meta-substituted dianiline monomer (m-DABA; see Figure 1 for its structure) via amidation and reduction based on previous research on a para-amide-substituted dianiline monomer (DABA; see Figure 1 for its structure) [18]. These two monomers are stereoisomers of each other, which enables us to further study the effect of spatial isomerism on the tight accumulation of PI molecular chain and gas permeability.

Next, m-DABA was polymerised with commercial pyromellitic dianhydride (PMDA, see Figure 1 for its structure) to prepare a PI film (m-DABPI, see Figure 1 for its structure) in a process similar to that for the DABA-based PI film. The thermal, mechanical, and barrier properties of the new film were tested. Wide-angle X-ray diffraction, positron annihilation lifetime spectroscopy (PALS), and molecular simulation were conducted to analyse the aggregation structure, free volume, chain mobility, molecular motion trajectory, diffusion coefficient, and solubility coefficient of the two polyimide materials (DABPI vs. m-DABPI), providing a detailed systematic exploration of the impact of substitution position on the barrier properties of PI. In summary, we try to change the spatial isomerization structure of monomers to develop a higher barrier polymer film, and the barrier mechanism is revealed.<smiles>O=c1oc(=O)c2cc3c(=O)oc(=O)c3cc12</smiles><smiles>Nc1ccc(NC(=O)c2ccc(Br)cc2)cc1</smiles><smiles>Nc1cccc(NC(=O)c2cccc(Br)c2)c1</smiles><smiles>Cc1ccc(C(=O)Nc2ccc(N3C(=O)c4cc5c(cc4C3=O)C(=O)C(C(C)(C)C)C5=O)cc2)cc1</smiles><smiles>CN1C(=O)c2cc3c(cc2[I+]1(C)C)C(=O)N(c1cccc(NC(=O)c2cccc(C(C)(C)C)c2)c1)C3=O</smiles>

Figure 1. The chemical structure of PMDA, DABA, 3-amino-N-(3-aminophenyl)benzamide (m-DABA),4-methyl-N-(4-(6-methyl-1,3,5,7-tetraoxo-3,5,6,7-tetrahydropyrrolo[3,4-f]isoindol2(1H)-yl)phenyl)benzamide (DABPI), and 3-methyl-N-(3-(6-methyl-1,3,5,7-tetraoxo-3,5,6,7tetrahydropyrrolo[3,4-f]isoindol-2(1H)-yl)phenyl)benzamide (m-DABPI).

\section{Materials and Methods}

\subsection{Materials}

m-nitroaniline, palladium $10 \%$ on activated carbon ( $10 \% \mathrm{Pd} / \mathrm{C})$, hydrazine monohydrate $\left(\mathrm{N}_{2} \mathrm{H}_{4} \cdot \mathrm{H}_{2} \mathrm{O}\right)$, 3-nitrobenzoyl chloride and 4,4'-Diaminobenzanilide (DABA) were purchased from Alfa-Aesar company and used as received. PMDA was purchased from Alfa-Aesar company and dried at $110{ }^{\circ} \mathrm{C}$ under vacuum for $6 \mathrm{~h}$ before use. Analytical grade absolute ethanol (EtOH), N,N-dimethylformamide (DMF), N-N-dimethylacetamide (DMAc), and pyridine (Py) were purchased from Sinopharm Chemical Reagent Co., Ltd. DMF was purified by distillation under inert nitrogen atmosphere. DMAc and Py were dried by $4 \mathrm{~A}$ molecular sieve for a week before use. Absolute ethanol was used without further purification.

\subsection{Instrumentation}

All characterisation methods are shown in the Supporting Information. 


\subsection{Synthesis of 3-Nitro-N-(3-Nitrophenyl)Benzamide(m-DABN)}

$\mathrm{m}$-nitroaniline $(6.906 \mathrm{~g}, 50 \mathrm{mmol})$ was placed in a $250 \mathrm{~mL}$ three-necked flask into which $100 \mathrm{~mL}$ of dry $\mathrm{N}, \mathrm{N}$ dimethylacetamide $\left(\mathrm{DMA}_{C}\right)$ and $14 \mathrm{~mL}$ of pyridine (Py) were sequentially added. The reactor was fully deoxygenated, filled with argon, and stirred at low temperature for $10 \mathrm{~min}$. The resulting mixture was slowly added to m-nitrobenzoyl chloride (10.206 g, $55 \mathrm{mmol})$, followed by $24 \mathrm{~h}$ stirring at room temperature. Next, the reaction mixture was poured into $2 \mathrm{~L}$ of water to allow for precipitate formation. After thoroughly washing the precipitate, the greyish-white product was collected and vacuumdried at $80{ }^{\circ} \mathrm{C}$ for $24 \mathrm{~h}$ with a yield of $80 \%(11.49 \mathrm{~g})$. IR $\left(\mathrm{KBr}, v, \mathrm{~cm}^{-1}\right): 1527\left(-\mathrm{NO}_{2}\right.$ stretching), 1652 ( $\mathrm{C}=\mathrm{O}$ stretching), 1347 ( $\mathrm{C}-\mathrm{N}$ stretching), 3307 ( $\mathrm{N}-\mathrm{H}$ stretching), 1100 $\sim 700$ (Ar-H stretching). ${ }^{1} \mathrm{H}$ NMR $\left(400 \mathrm{MHz}, \mathrm{DMSO}-d_{6}, \delta, \mathrm{ppm}\right): \delta 10.99(\mathrm{~s}, 1 \mathrm{H}), 8.88(\mathrm{t}$, $J=27.6 \mathrm{~Hz}, 1 \mathrm{H}), 8.81-8.73(\mathrm{~m}, 1 \mathrm{H}), 8.52-8.36(\mathrm{~m}, 2 \mathrm{H}), 8.22(\mathrm{~d}, J=7.6 \mathrm{~Hz}, 1 \mathrm{H}), 8.11-7.93(\mathrm{~m}$, $1 \mathrm{H}), 7.95-7.80(\mathrm{~m}, 1 \mathrm{H}), 7.69(\mathrm{t}, J=8.2 \mathrm{~Hz}, 1 \mathrm{H}) .{ }^{13} \mathrm{C}$ NMR $\left(100 \mathrm{MHz}, \mathrm{DMSO}-d_{6}, \delta, \mathrm{ppm}\right)$ : 164.24, 148.33, 148.23, 140.34, 135.98, 134.74, 130.77, 130.61, 127.03, 126.80, 122.94, 119.02, 115.06. MS (EI, $m / z)$ : 288(100) $\left(\left[\mathrm{M}^{+}+\mathrm{H}\right]\right.$, calcd for $\left.\mathrm{C}_{13} \mathrm{H}_{9} \mathrm{~N}_{3} \mathrm{O}_{5}, 287.05\right)$. Anal. calcd for $\mathrm{C}_{13} \mathrm{H}_{9} \mathrm{~N}_{3} \mathrm{O}_{5}$ : C, 54.36; $\mathrm{H}, 3.16$ and $\mathrm{N}, 14.63$; found: $\mathrm{C}, 54.31 ; \mathrm{H}, 3.19$ and $\mathrm{N}, 14.61$.

\subsection{Synthesis of 3-Amino-N-(3-Aminophenyl)Benzamide (m-DABA)}

m-DABN (2.872 g, $10 \mathrm{mmol})$ was placed in a three-necked flask into which $200 \mathrm{~mL}$ of absolute ethanol was added. The resulting mixture was fully deoxygenated and then filled with argon. After increasing the reactor temperature to $80^{\circ} \mathrm{C}$, a carbon-supported palladium $(\mathrm{Pd} / \mathrm{C})$ catalyst $(0.02 \mathrm{~g})$ was added, followed by the dropwise addition of $10 \mathrm{~mL}$ hydrazine hydrate to allow the reaction to take place under the argon atmosphere at $80{ }^{\circ} \mathrm{C}$ for $5 \mathrm{~d}$. Then, the reaction was terminated, and the reactor was allowed to cool to room temperature, followed by the vacuum filtration of the reaction mixture to remove the catalyst. The filtrate was rotary evaporated to a minimum amount and then allowed to crystallise at a low temperature to obtain a crystalline dianiline monomer, which was vacuum dried at $80{ }^{\circ} \mathrm{C}$ for $24 \mathrm{~h}$ for a yield of $85 \%(1.932 \mathrm{~g})$. IR $\left(\mathrm{KBr}, v, \mathrm{~cm}^{-1}\right): 3419(\mathrm{~N}-$ $\mathrm{H}$ stretching), $3336\left(-\mathrm{NH}_{2}\right.$ stretching), $1621(\delta \mathrm{N}-\mathrm{H}), 1645$ (C=O stretching), $1257(\mathrm{C}-\mathrm{N}$ stretching), $1100 \sim 700$ (Ar-H stretching). ${ }^{1} \mathrm{H}$ NMR (400 MHz, DMSO- $\left.d_{6}, \delta, \mathrm{ppm}\right): 9.89-9.67$ $(\mathrm{m}, 1 \mathrm{H}), 7.15-7.10(\mathrm{~m}, 2 \mathrm{H}), 7.08(\mathrm{~d}, J=1.5 \mathrm{~Hz}, 1 \mathrm{H}), 7.06-7.01(\mathrm{~m}, 1 \mathrm{H}), 6.95(\mathrm{t}, J=7.9 \mathrm{~Hz}, 1 \mathrm{H})$, $6.84(\mathrm{dd}, J=9.9,9.2 \mathrm{~Hz}, 1 \mathrm{H}), 6.73(\mathrm{ddd}, J=15.7,8.5,7.2 \mathrm{~Hz}, 1 \mathrm{H}), 6.35-6.23(\mathrm{~m}, 1 \mathrm{H}), 5.17(\mathrm{~d}$, $J=103.1 \mathrm{~Hz}, 4 \mathrm{H}) .{ }^{13} \mathrm{C}$ NMR (100 MHz, DMSO- $\left.d_{6}, \delta, \mathrm{ppm}\right): 166.63,149.30,149.13,140.40$, 136.81, 129.20, 129.16, 117.04, 115.22, 113.48, 110.04, 108.83, 106.53. MS (EI, $m / z): 228(100)$ $\left(\left[\mathrm{M}^{+}+\mathrm{H}\right]\right.$, calcd for $\left.\mathrm{C}_{13} \mathrm{H}_{13} \mathrm{~N}_{3} \mathrm{O}, 227.11\right)$. Anal. calcd for $\mathrm{C}_{13} \mathrm{H}_{13} \mathrm{~N}_{3} \mathrm{O}: \mathrm{C}, 68.70 ; \mathrm{H}, 5.77$ and $\mathrm{N}, 18.49$; found: $\mathrm{C}, 68.61 ; \mathrm{H}, 5.79$ and $\mathrm{N}, 18.52$.

\subsection{Synthesis of Polyimides ( $m-D A B P I)$}

In a clean room, m-DABA $(0.5454 \mathrm{~g}, 2.4 \mathrm{mmol})$ was placed in a round-bottomed flask into which $10 \mathrm{~mL}$ of dry $\mathrm{N}, \mathrm{N}^{\prime}$-dimethylformamide (DMF) was added to dissolve it, followed by the addition of PMDA $(0.5235 \mathrm{~g}, 2.4 \mathrm{mmol})$ with a solid content of $10 \mathrm{wt} . \%$. After filling the reactor with argon, the mixture was allowed to react at $0^{\circ} \mathrm{C}$ for $8 \mathrm{~h}$ to form a polyamic acid gel (m-DABPAA). After the gel was fully de-bubbled, it was scraped onto a clean glass plate. The thickness of the liquid film was controlled by adjusting the effective height of the scraper to control the thickness of the PI film. The liquid film was imidised in a high-temperature vacuum-drying oven with the following temperature ramp: room temperature to $100{ }^{\circ} \mathrm{C}(1 \mathrm{~h}), 100$ to $200{ }^{\circ} \mathrm{C}(1 \mathrm{~h}), 200$ to $300{ }^{\circ} \mathrm{C}(1 \mathrm{~h}), 300$ to $350{ }^{\circ} \mathrm{C}(0.5 \mathrm{~h})$, and natural cooling from $350^{\circ} \mathrm{C}$ to room temperature. Then, the PI film was peeled from the glass plate. IR $\left(\mathrm{KBr}, v, \mathrm{~cm}^{-1}\right)$ : 1775 and 1717 ( $\mathrm{C}=\mathrm{O}$ stretching), 1364 (C-N stretching), 1100 700 (Ar-H stretching). Anal. calcd for $\mathrm{C}_{23} \mathrm{H}_{11} \mathrm{~N}_{3} \mathrm{O}_{5}: \mathrm{C}, 67.48 ; \mathrm{H}, 2.71$ and N, 10.27; found: $\mathrm{C}, 67.39 ; \mathrm{H}, 2.75$ and $\mathrm{N}, 10.33$. DABPI was prepared from commercial DABA and PMDA by a similar process as M-DABPI. 


\subsection{Molecular Simulation}

Biovia Materials Studio software was employed to perform simulations in this study using the COMPASS (Condensed-phase Optimized Molecular Potentials for Atomistic Simulation Studies) forcefield [21,22]. Initially, polymer chains containing 25 repeat units were built and geometry optimization was performed. Then, a periodic model of the PI, comprising of 5 polymer chains in cubic unit cell, was constructed and the total energy of the system was minimized using smart minimizing method. Annealing was performed by the NPT (constant number of particles $(\mathrm{N})$, pressure $(\mathrm{P})$ and temperature $(\mathrm{T})$ ) dynamics procedure through heating and cooling the system at $1 \mathrm{~atm}$ in the temperature range of 300 to $1000 \mathrm{~K}$ in steps of $50 \mathrm{~K}$. Interactions of non-bond, van der Waals and electrostatic forces, were calculated using an atom-based summation method and an Ewald summation method, respectively. The annealed cell was later put through a stage-wise equilibration procedure. First the cell was heated to $1000 \mathrm{~K}$, and then the temperature was decreased in several stages to $600 \mathrm{~K}$ in steps of $100 \mathrm{~K}$. After this, the temperature was decreased in several stages to $400 \mathrm{~K}$ in steps of $50 \mathrm{~K}$ and then decreased to $300 \mathrm{~K}$ in steps of $25 \mathrm{~K}$. Each stage consisted of two consecutive NVT (constant number of particles $(\mathrm{N})$, volume $(\mathrm{V})$ and temperature (T)) and NPT runs at $1 \mathrm{~atm}$ and a specific temperature. The aim of the procedure was to obtain a refined system that would relax at the experimental density of the amorphous polymer at $1 \mathrm{~atm}$ and $300 \mathrm{~K}$. Finally, the cell was relaxed by consecutive NVT (at $300 \mathrm{~K}$ ) and NPT dynamics (at $1 \mathrm{~atm}$ and $298 \mathrm{~K}$ ) to ensure that a constant density has been reached. Two criteria were used to determine the equilibrium of the system: (1) The density of the system remained stable for a long time; (2) the fluctuation of energy was lower than 10\% [23]. The plots of density and energy versus simulation time in the last NPT for PI systems are shown in Figures S1 and S2, respectively. It can be seen that the PI systems have reached equilibrium states. The equilibrated densities of Kapton and FAPPI systems are 1.47 and $1.50 \mathrm{~g} / \mathrm{cm}^{3}$, respectively, which are fairly close to the experimental densities $\left(1.51\right.$ and $\left.1.53 \mathrm{~g} / \mathrm{cm}^{3}\right)$. In all runs, the Nosé method was used for temperature control [24]. In NPT runs, the pressure was controlled by Berendsen's method. During these simulations, the cutoff for the nonbonded interactions was taken as $15.5 \AA$.

The fractional free volume (FFV), hydrogen bonds, radius of gyration, radial distribution functions (RDFs), local mobility of polymer molecular chains, gas diffusion coefficient, and solubility coefficient of the two PI materials were investigated via molecular simulation and are elaborated in the Supporting Information.

\section{Results and Discussion}

\subsection{Synthesis and Characterisation of Monomers and Polyimides}

Dinitro-intermediate m-DABN was obtained by reacting m-nitrobenzoyl chloride and m-nitroaniline as raw materials at room temperature for $1 \mathrm{~d}$. m-DABN was catalytically reduced using $\mathrm{Pd} / \mathrm{C}$ and hydrazine hydrate to yield the dianiline monomer m-DABA with high purity. The synthesis route is shown in Scheme 1. m-DABA and the intermediate were characterised by NMR, FT-IR, elemental analysis, and mass spectrometry, and the results verified the success of the monomer synthesis. Figures S3 and S4 in the Supplementary Materials present the m-DABN NMR and MS spectra, respectively. Figure S5 presents the IR spectra of the two structures and presents the NMR spectrum of m-DABA. The NMR spectra of m-DABA are shown in Figure 2 and elemental analysis results are described in the experimental section. 


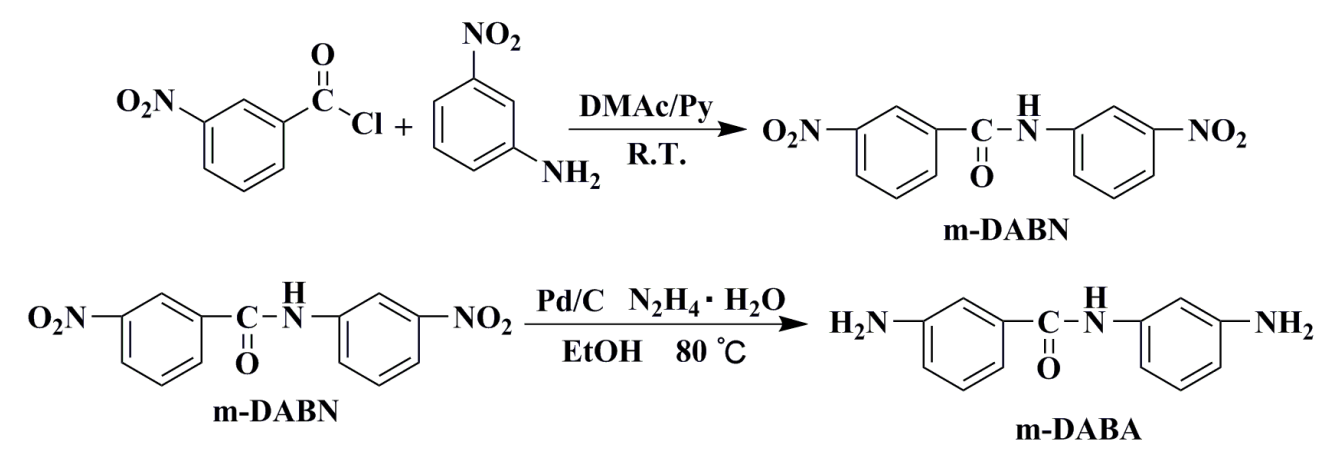

Scheme 1. m-DABA synthesis route.
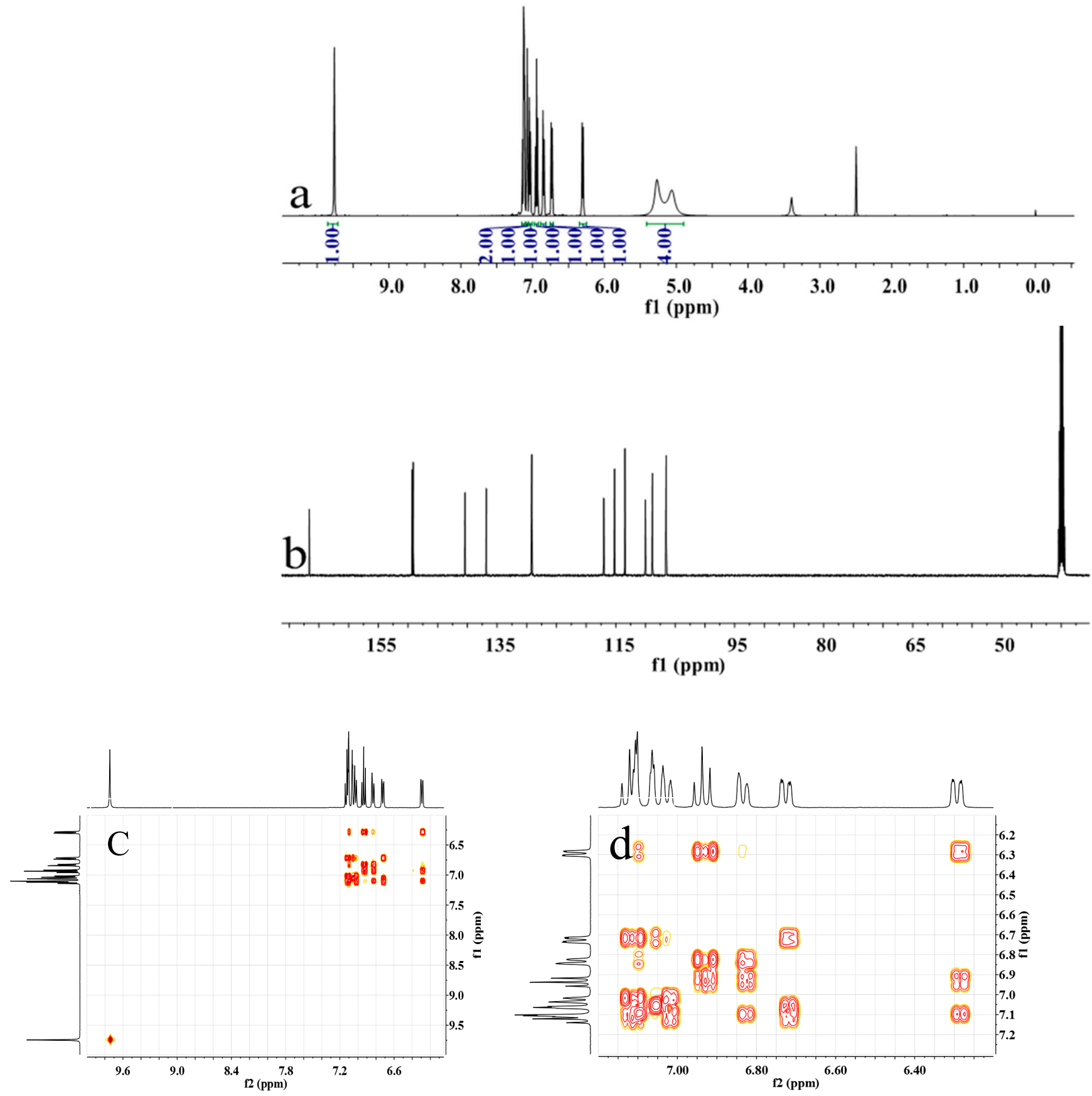

Figure 2. Cont. 

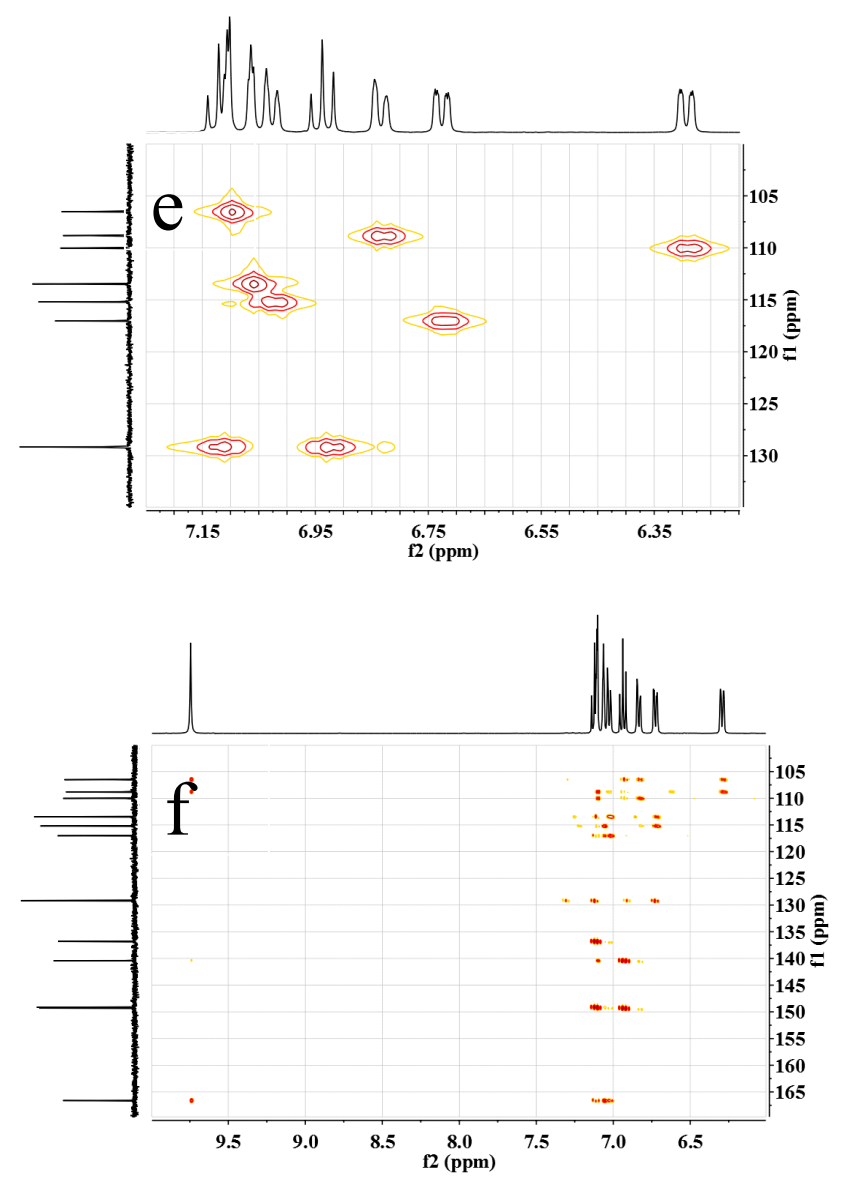

Figure 2. (a) ${ }^{1} \mathrm{H}$ NMR, (b) ${ }^{13} \mathrm{C}$ NMR, (c,d) H-H COSY, (e) C-H QC and (f) C-H BC spectra of m-DABPI in DMSO- $d_{6}$.

The high-viscosity precursor m-DABPAA was prepared by polymerising the same amount of m-DABA and PMDA at low temperatures. These materials were then thermally dehydrated and cyclised to yield PI (m-DABPI). The synthesis route is shown in Scheme 2. As m-DABPI did not dissolve in organic solvents, gel permeation chromatography (GPC) was used to determine the average molecular weight and molecular weight distribution of m-DABPAA. $M_{w}$ was $2.15 \times 10^{5}$, and the polydispersity index $\left(M_{w} / M_{n}\right)$ was 1.92 , indicating that the synthesized PI had a high molecular weight with a narrow distribution. Figure S5 presents the FT-IR spectrum of m-DABPI, which exhibits characteristic absorption peaks of imide groups at $1.364 \mathrm{~cm}^{-1}$ (stretching of $\mathrm{C}-\mathrm{N}$ ) as well as at 1775 and $1.13 \mathrm{~cm}^{-1}$ (stretching of carbonyl groups), in contrast to the IR spectrum of m-DABA. This indicates that the reaction between $\mathrm{m}-\mathrm{DABA}$ and PMDA was successful and imidisation was complete.

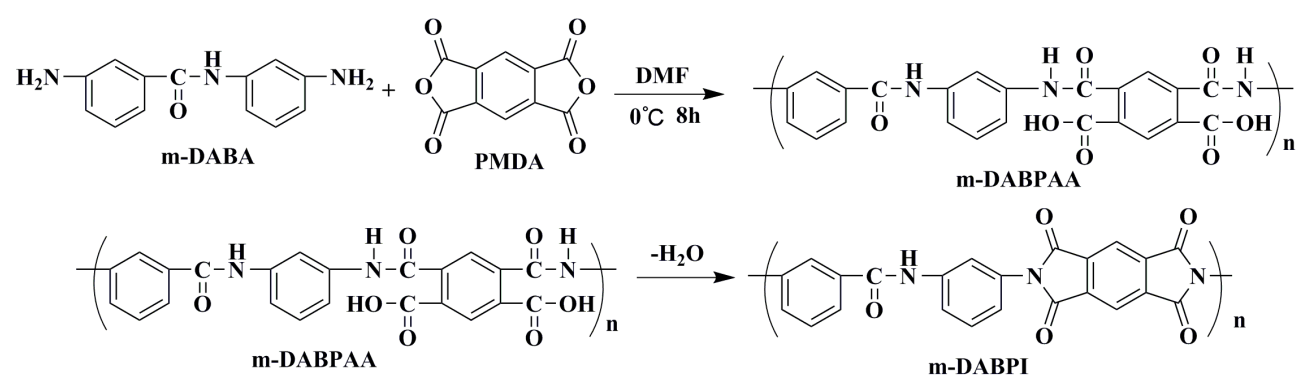

Scheme 2. Polyimide synthesis route.

\subsection{Thermal and Mechanical Properties}

The thermal properties of m-DABPI were investigated using DMA, TMA, and TGA; the resultant curves are shown in Figure S6, and the results are summarised in Table 1. 
The $5 \%$ and $10 \%$ weight-loss temperatures $\left(T_{d 5} \%\right.$ and $T_{d 10} \%$ ) of m-DABPI reached $498{ }^{\circ} \mathrm{C}$ and $522{ }^{\circ} \mathrm{C}$ respectively (Figure S6a), and the glass transition temperature (Tg) reached $364{ }^{\circ} \mathrm{C}$ (Figure S6b). The thermal expansion coefficient of $\mathrm{m}$-DABPI was $21.7 \mathrm{ppm} \cdot \mathrm{K}^{-1}$ at 50-300 ${ }^{\circ} \mathrm{C}$, (Figure S6c). Moreover, the PI had a tensile strength and tensile modulus of $131 \mathrm{MPa}$ and $4.1 \mathrm{GPa}$, respectively, showing excellent mechanical properties. The image of bent m-DABPI film (Figure S7) indicates that the PI film had good flexibility. The introduction of amide moieties led to a strong interchain force in the m-DABPI film, thereby giving it good thermal properties and excellent mechanical performance.

Table 1. Thermal and mechanical properties of the m-DABPI film.

\begin{tabular}{ccccccc}
\hline Polyimide & $\boldsymbol{T}_{\boldsymbol{g}}{ }^{\mathbf{a}}\left({ }^{\circ} \mathbf{C}\right)$ & $\boldsymbol{T}_{\boldsymbol{d} \mathbf{5} \%}\left({ }^{\circ} \mathbf{C}\right)$ & $\boldsymbol{T}_{\boldsymbol{d 1 0} \%}\left({ }^{\circ} \mathbf{C}\right)$ & $\begin{array}{c}\mathrm{CTE}^{\mathbf{b}} \\
\left(\mathbf{p p m} \cdot \mathbf{K}^{-\mathbf{1}}\right)\end{array}$ & $\begin{array}{c}\text { Tensile Strength } \\
\mathbf{( M P a})\end{array}$ & Tensile Modulus (GPa) \\
\hline m-DABPI & 364 & 498 & 522 & 21.7 & $131 \pm 3.0$ & $4.1 \pm 0.2$ \\
\hline
\end{tabular}

${ }^{a}$ Measured by DMA; ${ }^{b}$ CTE within the range of $50-300{ }^{\circ} \mathrm{C}$.

\subsection{Barrier Properties}

Barrier properties were compared between the present m-DABPI and the previously reported para-substituted PI (DABPI) as summarised in Table 2. The introduction of an amide moiety in the monomer led to excellent barrier properties in both PI materials but especially in m-DABPI, which had a water vapour transmission rate (WVTR) of $2.8 \mathrm{~g} \cdot \mathrm{m}^{-2} \cdot \mathrm{d}^{-1}$ and an oxygen transmission rate (OTR) of $3.3 \mathrm{~cm}^{3} \cdot \mathrm{m}^{-2} \cdot \mathrm{d}^{-1}$, amounting to $54.9 \%$ and $41.8 \%$ of the DABPI counterparts, respectively. This may be because the metasubstituted monomer better facilitated compact packing of the PI molecular chains, thereby reducing gas permeability and improving barrier properties. At the same time, compared with the traditional Kapton film, changing the molecular structure like m-DABPI to improve the barrier performance of PI will greatly reduce the inorganic and organic layers required by flexible display, and reduce the complexity and cost of production [14-16].

Table 2. Barrier properties of DABPI and m-DABPI films.

\begin{tabular}{|c|c|c|c|c|}
\hline PIs & $\begin{array}{c}\text { WVP } \\
\left(\mathrm{g} \cdot \mathrm{mil} \cdot \mathrm{m}^{-2} \cdot \mathrm{d}^{-1}\right)\end{array}$ & $\begin{array}{c}\text { OP } \\
\left(\mathrm{cm}^{3} \cdot \mathrm{mil} \cdot \mathrm{m}^{-2} \cdot \mathrm{d}^{-1}\right)\end{array}$ & $\begin{array}{c}\text { WVTR } \\
\left(\mathrm{g} \cdot \mathrm{m}^{-2} \cdot \mathrm{d}^{-1}\right)\end{array}$ & $\begin{array}{c}\text { OTR } \\
\left(\mathrm{cm}^{3} \cdot \mathrm{m}^{-2} \cdot \mathrm{d}^{-1}\right)\end{array}$ \\
\hline Kapton $^{\mathrm{a}}$ & I & 1 & $209.8 \pm 3.1$ & $657.3 \pm 3.8$ \\
\hline DABPI $^{a}$ & $3.6 \pm 0.2$ & $5.6 \pm 0.2$ & $5.1 \pm 0.3$ & $7.9 \pm 0.3$ \\
\hline m-DABPI & $2.0 \pm 0.2$ & $2.3 \pm 0.2$ & $2.8 \pm 0.2$ & $3.3 \pm 0.2$ \\
\hline
\end{tabular}

a The barrier properties values were obtained from Liu [18].

\subsection{Aggregation Structures Analysis}

The two PI materials were characterised via wide-angle X-ray diffraction (WAXD) to reveal their molecular chain-packing characteristics, thereby illustrating the impact of stereoisomerism on PI barrier properties. The WAXD curves of the two PI materials are shown in Figure 3. The molecular chain spacing in the two PI materials was calculated using the peak diffraction angle according to Bragg's equation [25], with the results shown in Table 3. The peak diffraction angle of DABPI was $20.5^{\circ}$, and the corresponding chain spacing was $4.33 \AA$. For m-DABPI, the peak diffraction angle was $21.7^{\circ}$, and the chain spacing was only $4.09 \AA$. Further, the density of the two PI materials was tested, and the results are shown in Table 3. m-DABPI had the larger density at $1.53 \mathrm{~g} \cdot \mathrm{cm}^{-3}$. The smaller chain spacing and higher density of m-DABPI indicate that the molecular chains of meta-substituted PI were packed more tightly in this monomer. 


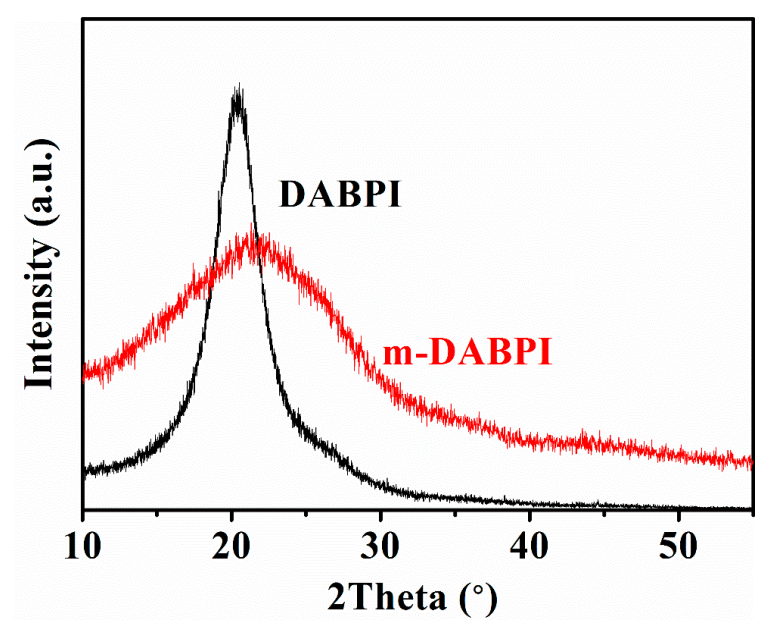

Figure 3. WAXD curve of DABPI and m-DABPI films.

Table 3. Physical properties of DABPI and m-DABPI.

\begin{tabular}{cccccc}
\hline PIs & Density $\left(\mathbf{g} \cdot \mathbf{c m}^{-\mathbf{3}}\right)$ & $\mathbf{2 \theta}\left({ }^{\circ}\right)$ & $d$-Spacing $(\AA)$ & $\mathbf{C E D}^{\mathbf{b}}\left(\mathbf{J} / \mathbf{c m}^{3}\right)$ & $\mathbf{N}^{\mathbf{c}} \mathbf{( H - B o n d s )}$ \\
\hline DABPI $^{\mathrm{a}}$ & 1.51 & 20.5 & 4.33 & 557 & 58 \\
m-DABPI & 1.53 & 21.7 & 4.09 & 612 & 60 \\
\hline
\end{tabular}

a The density, 20, $d$-spacing values were obtained from Liu [18]. ${ }^{\mathrm{b}} 1 \mathrm{~mol}$ of condensate per unit volume is the energy needed to overcome forced intermolecular vaporization. ${ }^{\mathrm{c}}$ Number of hydrogen bonds in the simulation cells.

\subsection{Hydrogen Bond Analysis}

Inter-chain forces are crucial to molecular chain packing in polymers. The radial distribution functions (RDFs) of DABPI and m-DABPI were calculated through molecular simulation to investigate the hydrogen-bonding force in the two PI materials. Theoretically, two types of hydrogen bonds may exist in each PI material, namely hydrogen bonds formed by the $-\mathrm{NH}$ - in amide moieties with the $\mathrm{O}=\mathrm{C}$ - in amide moieties and with the $\mathrm{O}=\mathrm{C}$ in imide rings. It has been reported that hydrogen-bonding forces exist only over the range of 0 to $3.1 \AA$, while van der Waals forces can exist at distances greater than $3.1 \AA$ [26]. The RDF diagrams of the two PI materials (Figure 4) exhibited obvious peaks near $1.9 \AA$ and $2.1 \AA$, indicating that the two PI materials were likely to form hydrogen bonds (shown in Figure 5). m-DABPI had a higher number of hydrogen bonds, 60, in the simulation box than did DABPI (Table 3). Thus, the results of these simulation-based calculations showed that m-DABPI had greater cohesive energy density than did DABPI (Table 3). More hydrogen bonds and greater cohesive energy density lead to stronger inter-chain forces, which in turn promote closer packing of molecular chains.
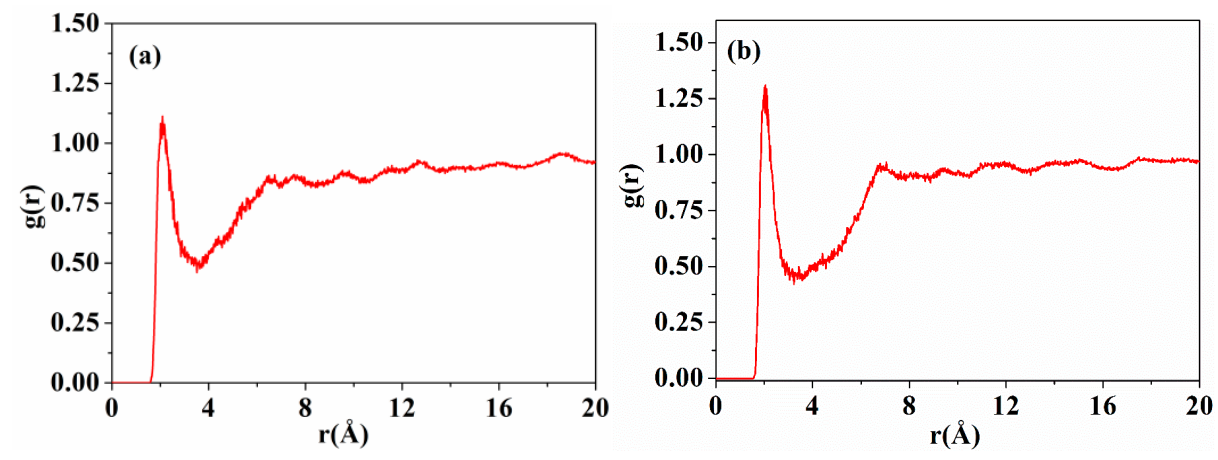

Figure 4. The RDFs of the hydrogen atoms of $-\mathrm{HN}$ - and oxygen atoms of $\mathrm{O}=\mathrm{C}$ - for DABPI (a) and m-DABPI (b). RDFs:Radial distribution function usually refers to the distribution probability of other particles in space given the coordinates of a given particle (how far away from the given particle). 


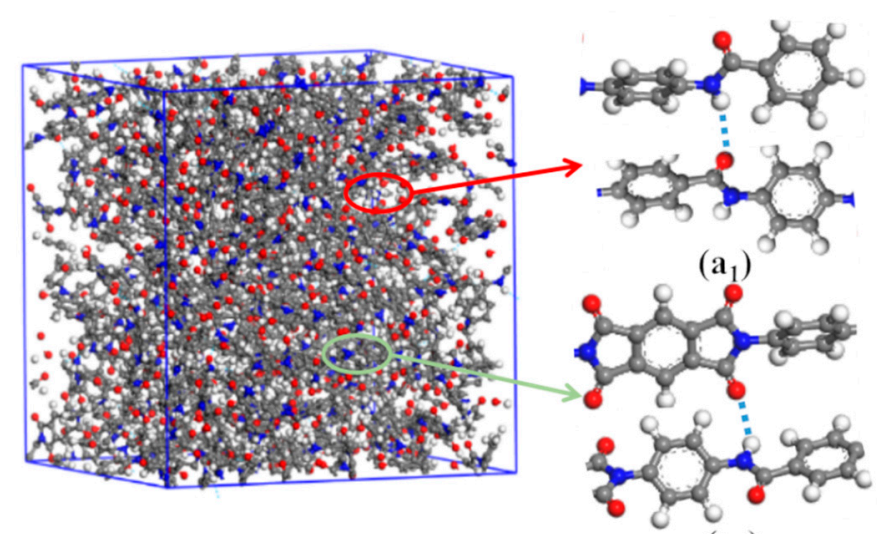

$\left(a_{2}\right)$

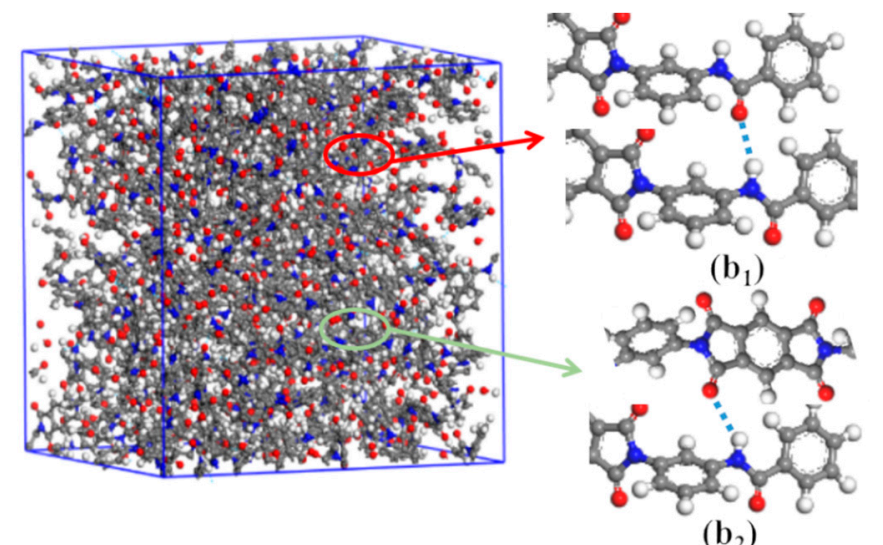

Figure 5. H-bonds in the simulation cell of DABPI $\left(\mathbf{a}_{1}, \mathbf{a}_{2}\right)$ and m-DABPI $\left(\mathbf{b}_{1}, \mathbf{b}_{2}\right)$. H-bonds between $-\mathrm{HN}$ - and $\mathrm{O}=\mathrm{C}$ - in amide groups $\left(\mathbf{a}_{1}, \mathbf{b}_{1}\right)$ and between $-\mathrm{HN}$ - and $\mathrm{O}=\mathrm{C}$ - in imide rings $\left(\mathbf{a}_{2}, \mathbf{b}_{2}\right)$.

\subsection{Free Volume and Cavity Size Distribution Analysis}

The free volume of DABPI and m-DABPI was characterised by PALS. Table 4 lists the positron lifetime components of the PI materials while Figure 6 presents the corresponding positron lifetime curves. These results were considered alongside previous research and relevant reports to calculate the free volume radius $(R)$, free volume size $\left(V_{f 2}\right)$, and fractional free volume (FFV) [17,27]. (Table 4). m-DABPI had smaller $\mathrm{V}_{\mathrm{f} 2}$ and FFV values than did DABPI. The average $V_{\mathrm{f} 2}$ was $41.63 \AA^{3}$ in DABPI and $38.79 \AA^{3}$ in the m-DABPI film, corresponding to FFVs of $7.28 \%$ and $6.77 \%$, respectively. The smaller $V_{\mathrm{f} 2}$ and FFV were attributed to the closer packing of molecular chains in the meta-substituted PI.

Table 4. Analyzed data of the positron lifetime and simulated FFV values in the DABPI and mDABPI films.

\begin{tabular}{cccccccccc}
\hline PIs & $\boldsymbol{\tau}_{\mathbf{1}}(\mathbf{n s})$ & $\boldsymbol{I}_{\mathbf{1}}(\mathbf{\%})$ & $\boldsymbol{\tau}_{\mathbf{2}}(\mathbf{n s})$ & $\boldsymbol{I}_{\mathbf{2}}(\mathbf{\%})$ & $\boldsymbol{R}(\AA)$ & $\begin{array}{c}\boldsymbol{V}_{f 2} \\
\left.\mathbf{( \AA}^{3}\right)\end{array}$ & $\boldsymbol{F F V ^ { \mathbf { a } }}$ & $\begin{array}{c}F F V^{\mathbf{b}} \\
\left(\mathbf{O}_{\mathbf{2}}\right)\end{array}$ & $\begin{array}{c}\boldsymbol{F F V}^{\mathbf{b}} \\
\left(\mathbf{H}_{\mathbf{2}} \mathbf{O}\right)\end{array}$ \\
\hline DABPI & 0.18 & 2.5 & 0.370 & 97.2 & 2.15 & 41.63 & 7.28 & 4.52 & 9.60 \\
m-DABPI & 0.19 & 2.6 & 0.368 & 97.0 & 2.10 & 38.79 & 6.77 & 3.95 & 9.03 \\
\hline
\end{tabular}

a $F F V$ was determined by PALS. ${ }^{\mathrm{b}}$ Free volume parameters calculated by simulations; $F F V\left(\mathrm{O}_{2}\right)$ and $F F V\left(\mathrm{H}_{2} \mathrm{O}\right)$ values are based on probe radii of $1.73 \AA$ and $1.325 \AA$, respectively. 


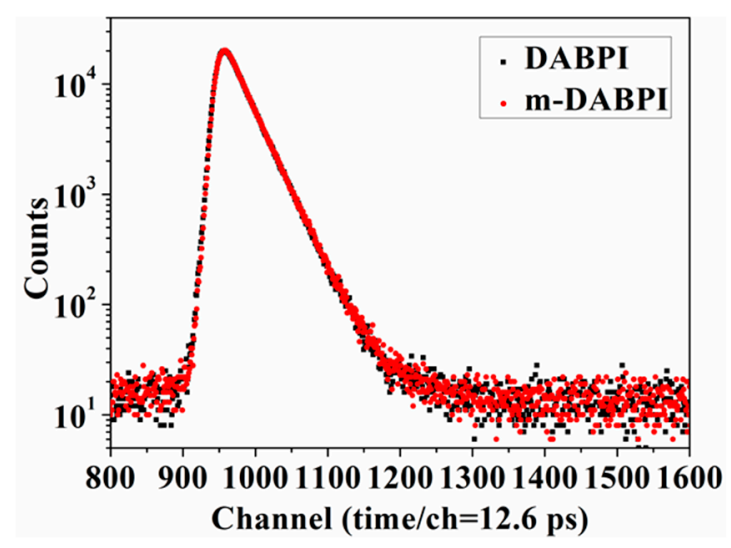

Figure 6. Positron lifetime spectra of DABPI and m-DABPI films.

Molecular simulation could elucidate the free volume connectivity and pore size distribution of polymers, thereby promoting a deeper understanding of PI barrier properties. Figure 7 a shows the relationship between the void radius ( 0 to $3 \AA$ ) and void percentage obtained through molecular simulation. Given that permeating molecules can only diffuse through voids with radii larger than their dynamic radius (which is $1.325 \AA$ and $1.73 \AA$ for $\mathrm{H}_{2} \mathrm{O}$ and $\mathrm{O}_{2}$, respectively), voids with radii greater than $1.2 \AA$ are considered effective. The peak radius in Figure $7 \mathrm{a}$ is about $0.8 \AA$, which is the radius of most voids. Such a small radius implies that the regions available for small molecule diffusion in the two PI materials were small. The percentage of voids with radii greater than $1.2 \AA$ was lower in $\mathrm{m}$-DABPI than in DABPI, indicating that the region for small molecule diffusion in m-DABPI was smaller than that in DABPI. These observations confirm that molecular chain linking via the meta-position served to improve PI barrier properties compared with the linking achieved via the para-position.
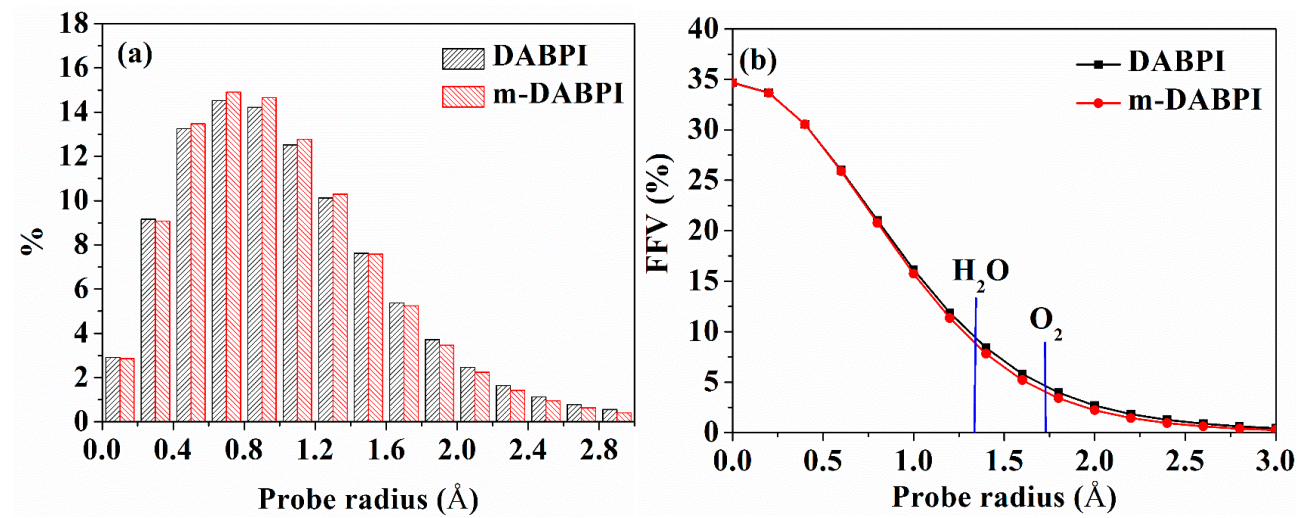

Figure 7. Distributions of void radii (a) and fractional free volume (b) as a function of probe radius in DABPI and m-DABPI. The kinetic radii of $\mathrm{O}_{2}$ and $\mathrm{H}_{2} \mathrm{O}$ are indicated by vertical lines.

In addition, the relationship between the radius of a spherical probe and FFV values was investigated (Figure 7b). The FFV of the two PI materials gradually decreased as the spherical probe radius increased, being lower in m-DABPI than in DABPI. When the spherical probe radius was equal to the dynamic radius of $\mathrm{H}_{2} \mathrm{O}$ and $\mathrm{O}_{2}$, the corresponding FFV was denoted as FFV $\left(\mathrm{O}_{2}\right)$ and $F F V\left(\mathrm{H}_{2} \mathrm{O}\right)$, respectively. Table 4 presents the FFVs of the two PI materials when $\mathrm{H}_{2} \mathrm{O}$ and $\mathrm{O}_{2}$ molecules were separately used as the probe. The results obtained via both molecular probes showed that compared with DABPI, m-DABPI had a smaller free volume, which indicated that m-DABPI was less conducive for the permeation of small molecules. Figure 8 presents the simulated morphology of free volume sensed via separate $\mathrm{H}_{2} \mathrm{O}$ and $\mathrm{O}_{2}$ probes (the blue areas denote voids). As shown in Figure 8, 
m-DABPI has fewer blue areas and a smaller free volume than DABPI, which is consistent with the more compact packing of molecular chains in m-DABPI.
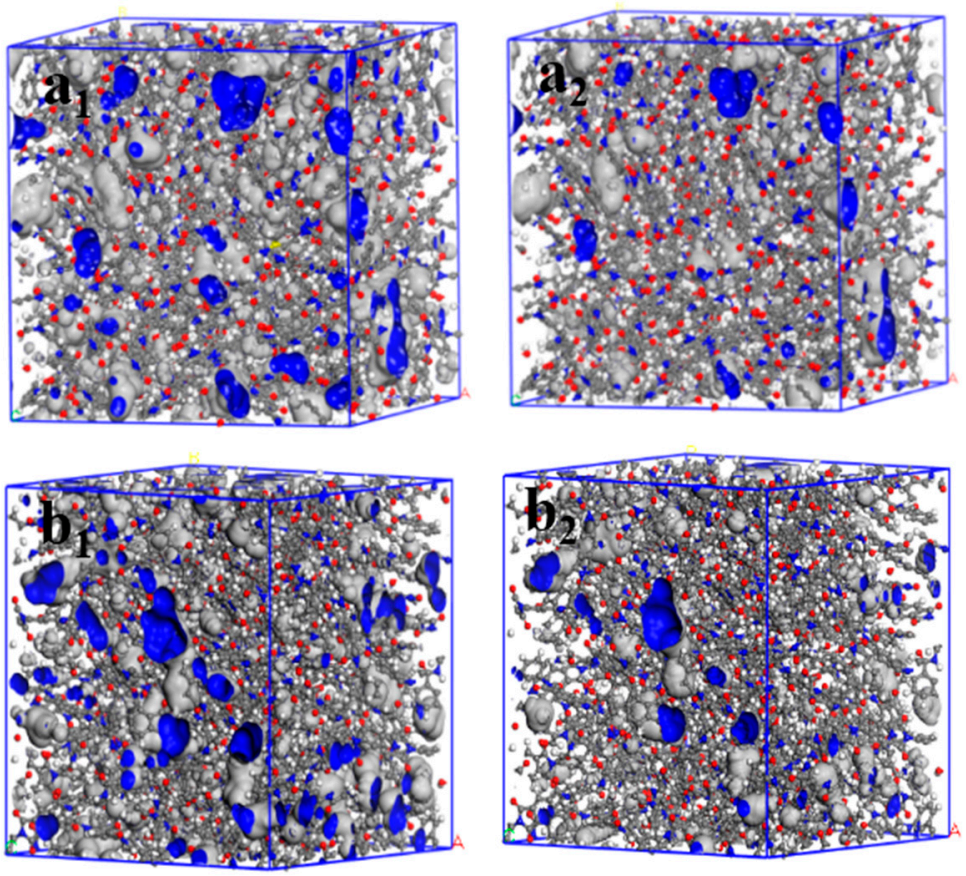

Figure 8. Three-dimensional representation of $\mathrm{H}_{2} \mathrm{O}$ and $\mathrm{O}_{2}$ accessible volume in (a1,a2) DABPI, and $(\mathbf{b} 1, \mathbf{b} 2)$ m-DABPI (grey: Van der Waals surface; blue: Connolly surface; a1 and b1: probe radius of $1.325 \AA$; a2 and b2: probe radius of $1.73 \AA$ ).

\subsection{Local Mobility of Polymer Chains}

Small molecules diffuse in a polymer film by jumping from one void to another through the channel transiently formed via molecular chain motion [28]. Therefore, the local mobility of molecular chains is crucial for gas barrier properties. The higher the local mobility of molecular chains, the easier the gas diffusion [29,30]. Mean square displacement (MSD) in the two PI materials was separately calculated via molecular simulation. Figure 9 presents MSD as a function of time up to 5000 ps in the two PI materials. A larger MSD value indicates greater molecular chain mobility. Compared with DABPI, it is more difficult for m-DABPI to form a diffusion channel for small molecules due to its weaker chain mobility. This property contributes to m-DABPI's stronger barrier properties.

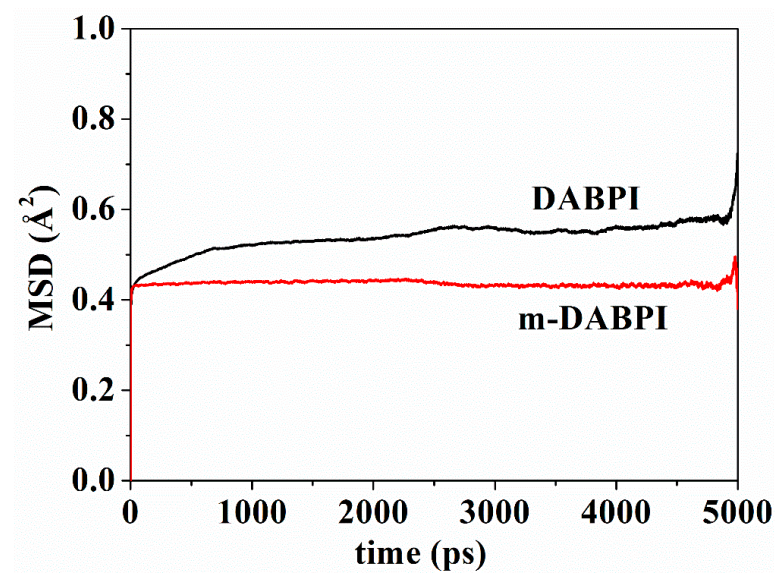

Figure 9. MSD of polymer chains as a function of time in DABPI and m-DABPI. 


\subsection{Gas Transport Behaviour}

Molecular simulation of gas diffusion and dissolution in the two PI materials was performed to gain deeper insights into their gas permeability.

\subsubsection{Gas Diffusion}

The diffusion of gas molecules in a polymer film can be approximated as the random movement of small molecules in the film [31]. Figure 10 illustrates the diffusion trajectories of $\mathrm{H}_{2} \mathrm{O}$ and $\mathrm{O}_{2}$ as representative small molecules over a period of $10 \mathrm{~ns}$ in the two PI materials, and Figure S8 presents the corresponding $\left|r_{i}(t)-r_{i}(0)\right|$ values through which the displacement curve of m-DABPI is translated. Figure 10 and Figure $S 8$ clearly indicate that the two types of gas molecules have shorter trajectories and displacements in $\mathrm{m}$ DABPI than in DABPI, which is attributable to the fact that the molecular chains of $\mathrm{m}$ DABPI are more compactly packed and have a smaller free volume, thereby limiting small molecule diffusion.
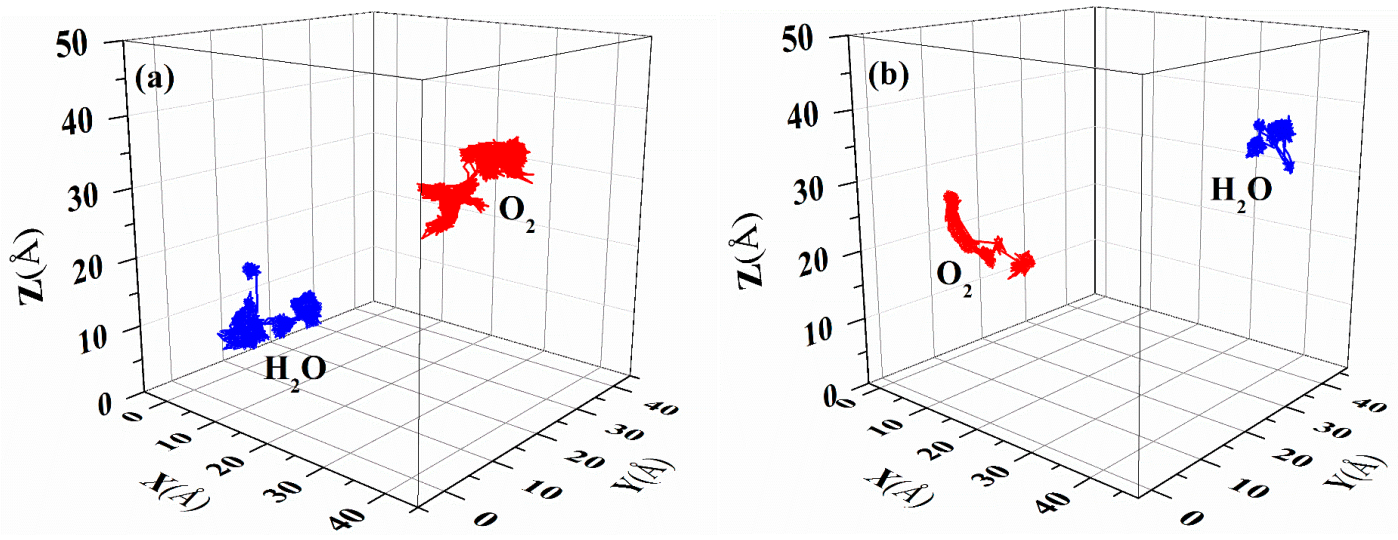

Figure 10. Representative trajectories of $\mathrm{O}_{2}$ and $\mathrm{H}_{2} \mathrm{O}$ in (a) DABPI and (b) m-DABPI.

The relationship between MSD and time was plotted on logarithmic scales (Figure 11). The diffusion coefficient of the penetrating molecules in the PI materials was derived according to the corresponding Einstein equation [32]. The results (Table 5) showed that the diffusion coefficient was lower in m-DABPI than in DABPI. This was attributable to the smaller free volume and thereby more limited gas diffusion in m-DABPI, which was consistent with the diffusion trajectories. However, $\mathrm{H}_{2} \mathrm{O}$, which has a smaller dynamic radius than does $\mathrm{O}_{2}$, had a smaller diffusion coefficient in this study, which was attributed to the fact that the two PI materials contained strong hydrogen-bonding forces and thereby limited the diffusion of $\mathrm{H}_{2} \mathrm{O}$ [33]. As shown above, the substitution position impacts the gas diffusion properties of PI, with meta-substitution being unfavourable for small molecule diffusion.

Table 5. Simulated diffusion coefficients (D), solubility coefficients (S), and permeability (P) for $\mathrm{O}_{2}$ and $\mathrm{H}_{2} \mathrm{O}$ in DABPI and $\mathrm{m}-\mathrm{DABPI}$.

\begin{tabular}{|c|c|c|c|c|c|c|}
\hline \multirow{2}{*}{ PIs } & \multicolumn{2}{|c|}{$D^{a}$} & \multicolumn{2}{|c|}{$S^{b}$} & \multicolumn{2}{|c|}{$P^{c}$} \\
\hline & $\mathrm{H}_{2} \mathrm{O}$ & $\mathrm{O}_{2}$ & $\mathrm{H}_{2} \mathrm{O}$ & $\mathrm{O}_{2}$ & $\mathrm{H}_{2} \mathrm{O}$ & $\mathrm{O}_{2}$ \\
\hline DABPI & 1.7 & 4.82 & 0.41 & 0.045 & 0.70 & 0.22 \\
\hline m-DABPI & 1.2 & 3.19 & 0.39 & 0.038 & 0.47 & 0.12 \\
\hline
\end{tabular}




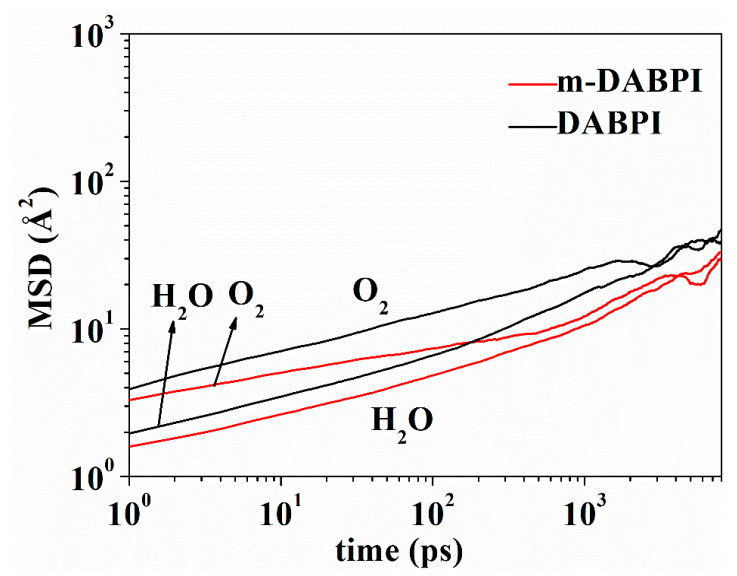

Figure 11. MSD of $\mathrm{O}_{2}$ and $\mathrm{H}_{2} \mathrm{O}$ in DABPI and m-DABPI as a function of time.

\subsubsection{Gas Solubility}

Molecular simulation of the adsorption isotherms of $\mathrm{H}_{2} \mathrm{O}$ and $\mathrm{O}_{2}$ in the two PI films was performed to gain deeper insights into their dissolution behaviour in the materials. the solubility describes the concentration of the gas inside a polymer at equilibrium with the gas at a partial pressure and is often described by the dual-mode sorption theory; As shown by the four simulated adsorption isotherms in Figure 12, rapid adsorption occurs under low pressure, which mainly occurs in inter-chain voids, while slow desorption occurs under high pressure, which mainly occurs in the intra-chain free volume. These two processes coincide with Langmuir-mode adsorption and Henry-mode adsorption, respectively [34]. Moreover, solubility coefficients were derived from the adsorption isotherms, and the results (Table 5) showed that m-DABPI had smaller solubility coefficients than DABPI. This is because $\mathrm{m}$-DABPI has a smaller free volume and therefore fewer adsorption sites.

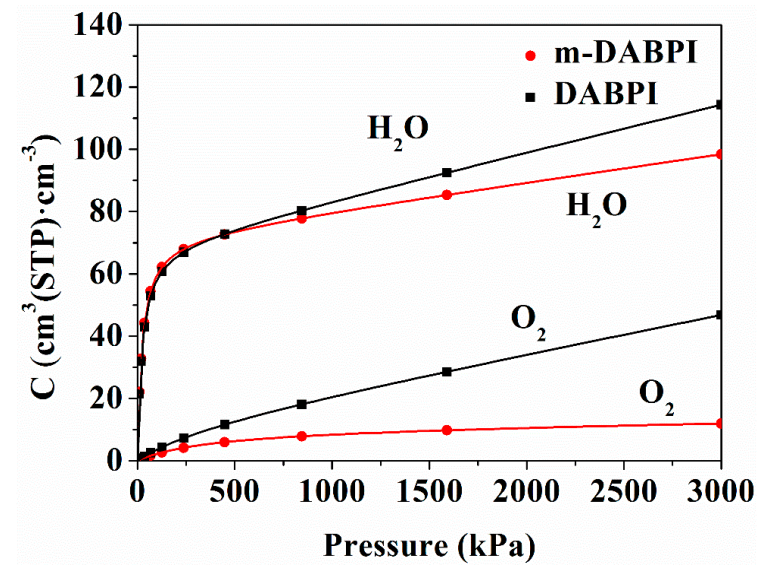

Figure 12. Adsorption isotherms of $\mathrm{O}_{2}$ and $\mathrm{H}_{2} \mathrm{O}$ in DABPI and m-DABPI.

\subsubsection{Gas Permeability}

Permeability coefficients $(\mathrm{P})$ were calculated as the product of diffusion coefficients (D) and solubility coefficients (S) according to the dissolution-diffusion mechanism [35]. The results (Table 5) showed that compared with DABPI, m-DABPI had smaller permeability coefficients, which was attributed to its smaller diffusion coefficients and solubility coefficients. The results showed a trend consistent with that of the experimentally derived permeability coefficients in this study, indicating the high reliability of the simulated results. In summary, therefore, PI synthesised from meta-substituted monomers has better barrier properties, because meta-substitution is more favourable for the close packing of molecular chains and therefore leads to a smaller free volume and reduced mobility. 


\section{Conclusions}

The present study designed and synthesised the meta-substituted dianiline monomer m-DABA as a stereoisomer of the previously investigated para-substituted dianiline monomer DABA, and polymerised m-DABA with PMDA to prepare PI in a process similar to that employed in the previous study. The impact of substitution position on the barrier properties of polyimide was investigated. The results showed that the introduction of amide moieties led to good barrier properties in the two polyimide materials, especially the meta-substituted polyimide. Moreover, an in-depth analysis was performed via WXAD, PALS, and molecular simulation, revealing that meta-substitution better promoted the close packing of molecular chains in the polymer to yield a small free volume, thereby inhibiting to some extent the dissolution and diffusion of permeating molecules in the polymer film. Further, the molecular chains of m-DABPI had poor mobility, which was not conducive to the diffusion of permeating molecules. Taken together, these factors resulted in lower permeability coefficients for m-DABPI, which are indicative of better barrier properties. In addition, m-DABPI maintained good thermal and mechanical properties. These findings have significant implications for the structural design importance of high-barrier materials which could advance the development of flexible display technology.

Supplementary Materials: The following are available online at https:/ / www.mdpi.com/article/10

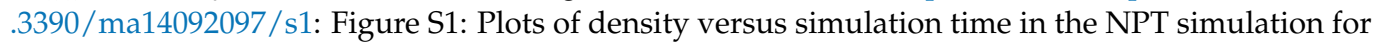
DABPI and m-DABPI. Figure S2: Plots of energy versus simulation time in the NPT simulation for (a) DABPI and (b) m-DABPI. Figure S3: ${ }^{1} \mathrm{H}$ NMR (a), ${ }^{13} \mathrm{C}$ NMR (b) and MS (c) spectra of m-DABN. Figure S4: MS spectrum of m-DABA. Figure S5: FT-IR spectra of m-DABN, m-DABA and m-DABPI. Figure S6: TGA (a), DMA (b) and TMA (c) curve of m-DABPI film. Figure S7: Photo image of the flexible m-DABPI film. Figure S8: Displacement of $\mathrm{O}_{2}$ and $\mathrm{H}_{2} \mathrm{O}$ from their initial positions in DABPI and $\mathrm{m}$-DABPI.

Author Contributions: Conceptualization, Q.W. and A.T.; methodology, Q.W. and A.T.; software, C.C. and C.X.; validation, Q.W., Y.L. and J.T.; formal analysis, Q.W. and C.X.; investigation, Q.W.; resources, D.L.; data curation, Q.W.; writing—original draft preparation, Q.W. and D.L.; writing-review and editing, Q.W., A.T., Y.L. and D.L.; visualization, J.T., C.C. and C.X.; supervision, D.L.; project administration, D.L. All authors have read and agreed to the published version of the manuscript.

Funding: This work was financially supported by the Key Research and Development Project of Hunan Province (2018GK2063).

Institutional Review Board Statement: Not applicable.

Informed Consent Statement: Not applicable.

Data Availability Statement: The data used to support the findings of this study are available from the corresponding author upon request.

Conflicts of Interest: The authors declare that there are no conflicts of interest regarding the publication of this paper.

\section{References}

1. Calle, M.; García, C.; Lozano, A.E.; Jose, G.; de Abajo, J.; Álvarez, C. Local chain mobility dependence on molecular structure in polyimides with bulky side groups: Correlation with gas separation properties. J. Membr. Sci. 2013, 434, 121-129. [CrossRef]

2. Liaw, D.J.; Huang, C.C.; Chen, W.H. Color lightness and highly organosoluble fluorinated polyamides polyimides and poly (amideimide)s based on noncoplanar 2, 2-dimethyl-4, 4'-biphenylene units. Polymer 2006, 47, 2337-2348. [CrossRef]

3. Wu, Y.; Liu, S.; Chen, Z.; Zhao, J. Synthesis and properties of cardo-type polyimides containing hydroxyl groups for application in specific detection of fluoride ion. Dye. Pigment. 2020, 173, 107924. [CrossRef]

4. Liaw, D.-J.; Wang, K.-L.; Huang, Y.-C.; Lee, K.-R.; Lai, J.-Y.; Ha, C.-S. Advanced polyimide materials: Syntheses, physical properties and applications. Prog. Polym. Sci. 2012, 37, 907-974. [CrossRef]

5. Lee, J.; Lee, Y.; Kang, T.; Chu, H.; Kwag, J. Alleviation of abnormal NBTI phenomenon in LTPS TFTs on polyimide substrate for flexible AMOLED. J. Soc. Inf. Disp. 2020, 28, 333-341. [CrossRef]

6. Patil, S.U.; Radue, M.S.; Pisani, W.A.; Deshpande, P.; Xu, H.; Al Mahmud, H.; Dumitrică, T.; Odegard, G.M. Interfacial characteristics between flattened CNT stacks and polyimides: A molecular dynamics study. Comput. Mater. Sci. 2020, 185, 109970. [CrossRef] 
7. Choi, M.-C.; Kim, Y.; Ha, C.-S. Polymers for flexible displays: From material selection to device applications. Prog. Polym. Sci. 2008, 33, 581-630. [CrossRef]

8. Heremans, P.P.; Tripathi, A.K.; Meux, A.D.J.D.; Smits, E.C.P.; Hou, B.; Pourtois, G.; Gelinck, G.H. Mechanical and Electronic Properties of Thin-Film Transistors on Plastic, and Their Integration in Flexible Electronic Applications. Adv. Mater. 2016, 28, 4266-4282. [CrossRef]

9. Lewis, J. Material challenge for flexible organic devices. Mater. Today 2006, 9, 38-45. [CrossRef]

10. Park, J.S.; Kim, T.W.; Stryakhilev, D.; Lee, J.S.; An, S.G.; Pyo, Y.S.; Lee, D.B.; Mo, Y.G.; Jin, D.U.; Chung, H.K. Flexible full color organic light-emitting diode display on polyimide plastic substrate driven by amorphous indium gallium zinc oxide thin-film transistors. Appl. Phys. Lett. 2009, 95, 013503. [CrossRef]

11. Gao, X.; Lin, L.; Liu, Y.; Huang, X. LTPS TFT Process on Polyimide Substrate for Flexible AMOLED. J. Disp. Technol. 2015, 11, 666-669. [CrossRef]

12. Tseng, I.H.; Chang, C.J.; Chang, C.W.; Lu, H.H.; Tsai, M.H. Effect of magnetron sputtered silicon nitride on the water-vaporpermeation-rate of polyimide thin film. Surf. Coat. Technol. 2013, 231, 496-500. [CrossRef]

13. Liu, Y.W.; Liu, J.J.; Ding, Q. Enhanced gas barrier and thermal properties of polyimide/montmorillonite nanocomposites as a result of "dual-plane" structure effect. Polym. Compos. 2017, 39, E1725-E17325. [CrossRef]

14. Liu, Y.-W.; Huang, J.; Tan, J.-H.; Zeng, Y.; Ding, Q.; Xiang, X.-W.; Liu, Y.-J.; Zhang, H.-L. Synthesis and characterization of intrinsic high-barrier polyimide derived from a novel diamine monomer containing rigid planar moiety. J. Polym. Sci. Part A Polym. Chem. 2017, 55, 2373-2382. [CrossRef]

15. Liu, Y.; Huang, J.; Tan, J.; Zeng, Y.; Liu, J.; Zhang, H.; Pei, Y.; Xiang, X.; Liu, Y. Intrinsic high-barrier polyimide with low free volume derived from a novel diamine monomer containing rigid planar moiety. Polymer 2017, 114, 289-297. [CrossRef]

16. Tan, J.; Wang, Q.; Liu, Y.; Zeng, Y.; Ding, Q.; Wu, R.; Liu, Y.; Xiang, X. Synthesis, gas barrier and thermal properties of polyimide containing rigid planar fluorene moieties. J. Macromol. Sci. Part A 2018, 55, 75-84. [CrossRef]

17. Liu, Y.; Huang, J.; Tan, J.; Zeng, Y.; Ding, Q.; Zhang, H.; Liu, Y.; Xiang, X. Barrier and thermal properties of polyimide derived from a diamine monomer containing a rigid planar moiety. Polym. Int. 2017, 66, 1214-1222. [CrossRef]

18. Liu, J.-J.; Tan, J.-H.; Zeng, Y.; Liu, Y.-W.; Zeng, K.-J.; Liu, Y.-J.; Wu, R.-M.; Chen, H. Synthesis and characterization of high-barrier polyimide containing rigid planar moieties and amide groups. Polym. Test. 2017, 61, 83-92. [CrossRef]

19. Simons, K.; Nijmeijer, D.K.; Sala, J.G.; Van Der Werf, J.H.; Benes, N.E.; Dingemans, T.J.; Wessling, M.M. CO 2 sorption and transport behavior of ODPA-based polyetherimide polymer films. Polymer 2010, 51, 3907-3917. [CrossRef]

20. Comesaña-Gándara, B.; Calle, M.; Jo, H.J.; Hernández, A.; de la Campa, J.G.; de Abajo, J.; Lozano, A.E.; Lee, Y.M. Thermally rearranged polybenzoxazoles membranes with biphenyl moieties: Monomer isomeric effect. J. Membr. Sci. 2014, 450, 369-379. [CrossRef]

21. Sun, H. COMPASS: An ab Initio Force-Field Optimized for Condensed-Phase ApplicationsOverview with Details on Alkane and Benzene Compounds. J. Phys. Chem. B 1998, 102, 7338-7364. [CrossRef]

22. Sun, H.; Ren, P.; Fried, J. The COMPASS force field: Parameterization and validation for phosphazenes. Comput. Polym. Sci. 1998, 8, 229-246. [CrossRef]

23. Zhu, J.; Zhao, X.; Liu, L.; Song, M.; Wu, S. Quantitative relationships between intermolecular interaction and damping parameters of irganox-1035/NBR hybrids: A combination of experiments, molecular dynamics simulations, and linear regression analyses. $J$. Appl. Polym. Sci. 2018, 135, 46202. [CrossRef]

24. Nosé, S. A unified formulation of the constant temperature molecular dynamics methods. J. Chem. Phys. 1984, 81, 511. [CrossRef]

25. La Cruz, D.S.-D.; Green, M.D.; Ye, Y.; Elabd, Y.A.; Long, T.E.; Winey, K.I. Correlating backbone-to-backbone distance to ionic conductivity in amorphous polymerized ionic liquids. J. Polym. Sci. Part B Polym. Phys. 2011, 50, 338-346. [CrossRef]

26. Mattozzi, A.; Hedenqvist, M.S.; Gedde, U.W. Diffusivity of n-hexane in poly(ethylene-stat-octene)s assessed by molecular dynamics simulation. Polymer 2007, 48, 5174-5180. [CrossRef]

27. Liao, K.S.; Chen, H.; Awad, S.; Yuan, J.P.; Hung, W.S.; Lee, K.R.; Lai, J.Y.; Hu, C.C.; Jean, Y.C. Determination of Free-Volume Properties in Polymers Without Orthopositronium Components in Positron Annihilation Lifetime Spectroscopy. Macromolecules 2011, 44, 6818-6826. [CrossRef]

28. Park, S.; Lee, A.S.; Do, Y.S.; Kim, J.F.; Hwang, S.S.; Lee, Y.M.; Lee, J.H.; Lee, J.S. Side-chain engineering of ladder-structured polysilsesquioxane membranes for gas separations. J. Membr. Sci. 2016, 516, 202-214. [CrossRef]

29. Luo, Z.; Yang, Z.; Fei, Z.; Li, K. Effect of crosslinking rate on the glass transition temperature of polyimide cross-linked silica aerogels. J. Polym. Res. 2020, 27, 1-9. [CrossRef]

30. Li, M.; Liu, X.Y.; Qin, J.Q.; Gu, Y. Molecular dynamics simulation on glass transition temperature of isomeric polyimide. Express Polym. Lett. 2009, 3, 665-675. [CrossRef]

31. Neyertz, S.; Brown, D.; Pandiyan, S.; Van Der Vegt, N.F.A. Carbon Dioxide Diffusion and Plasticization in Fluorinated Polyimides. Macromol. 2010, 43, 7813-7827. [CrossRef]

32. Mozaffari, F.; Eslami, H.; Moghadasi, J. Molecular dynamics simulation of diffusion and permeation of gases in polystyrene. Polymer 2010, 51, 300-307. [CrossRef]

33. Zhang, K.; Yu, Q.; Zhu, L.; Liu, S.; Chi, Z.; Chen, X.; Zhang, Y.; Xu, J. The Preparations and Water Vapor Barrier Properties of Polyimide Films Containing Amide Moieties. Polymer 2017, 9, 677. [CrossRef] 
34. Petropoulos, J.H. Petropoulos and A GENERALIZED, A Generalized, Topologically Consistent, Dual-mode Transport Model for Glassy Polymer-Gas Systems. J. Polym. Sci. Part B Polym. Phys. 1989, 27, 603-620. [CrossRef]

35. Ghasemnejad-Afshar, E.; Amjad-Iranagh, S.; Zarif, M.; Modarress, H. Effect of side branch on gas separation performance of triptycene based PIM membrane: A molecular simulation study. Polym. Test. 2020, 83, 106339. [CrossRef] 